\title{
Myotonic dystrophy : investigation of the proposed defect in guanidoacetic acid synthesis
}

\author{
C. E. BOLTON ${ }^{1}$ AND A. E. H. EMERY \\ From the University Department of Human Genetics, Western General Hospital, Edinburgh
}

SUMMARY No significant abnormality was detected in plasma levels or urinary excretion of guanidoacetic acid (GAA) in patients with myotonic dystrophy. It therefore seems unlikely that there is defective synthesis of GAA in this disorder. It was confirmed that arginine-glycine amidinotransferase (AGA), the enzyme responsible for GAA synthesis, is present in renal cortical tissue, but no enzyme activity could be detected in a variety of other, more accessible tissues taken from healthy controls.

Myotonic dystrophy is a dominantly inherited disorder, the biochemical basis of which is unknown. It has been known for many years that a number of diseases with muscle wasting are characterized by an increased urinary excretion of creatine, which is believed to be secondary to the reduction in functioning muscle tissue (Milhorat, 1953). Various studies have shown that in myotonic dystrophy, however, urinary creatine levels are either normal or only slightly raised (Zierler, Folk, Magladery, and Lilienthal, 1949; Van Pilsum and Wolin, 1958). It has been suggested that the absence of excessive creatinuria in myotonic dystrophy may be due to defective synthesis of creatine (Zierler et al., 1949), and Harvey (1969) has reported a reduction in arginine-glycine amidinotransferase (AGA; EC $2,1,4,1)$ activity in renal cortical tissue from two patients with myotonic dystrophy. This enzyme is responsible for the formation of guanidoacetic acid (GAA), an intermediate in the synthesis of creatine, and is known to occur in human kidney cortex, pancreas and liver (Walker, 1963). However studies of GAA excretion in myotonic dystrophy have provided conflicting results. Van Pilsum and Wolin (1958) found that in myotonic dystrophy urinary GAA levels were elevated, whereas Harvey (1962) reported reduced levels in this condition.

The aim of the present study was to establish

1 C.E.B. is in receipt of a Kirk Duncanson Fellowship of the Royal College of Physicians of Edinburgh. whether there is a defect in the synthesis of GAA in myotonic dystrophy. The problem was approached in two ways: firstly, by comparing plasma and urinary GAA levels in patients and healthy controls and, secondly, because of the obvious difficulties of obtaining biopsy specimens of kidney, pancreas, and liver, by investigating whether AGA activity could be detected in more accessible tissues. If enzyme activity could be demonstrated in easily accessible tissues, it might then be possible to investigate in greater detail the reported decrease in enzyme activity in patients with myotonic dystrophy.

\section{METHODS}

SUBJECTS The diagnosis of myotonic dystrophy was established on the basis of clinical examination, electromyography, and in some cases, muscle histology. The patients varied from those who were minimally affected to those who were chair-ridden and severely incapacitated. Healthy individuals with no history of any neuromuscular disorder were used as controls.

GUANIDOACETIC ACID ESTIMATION The method used was a modification of that described by Van Pilsum, Martin, Kito, and Hess (1956). All estimations were carried out on fresh material. Blood was obtained by venepuncture after an overnight fast and collected in heparinized tubes. Plasma and red cells were separated by centrifugation at $500 \mathrm{~g}$ for $10 \mathrm{~min}$. It was confirmed that GAA is absent from erythrocytes (Sandberg, Hecht and Tyler, 1953). Twenty-four 
hour urine specimens were collected with a few small crystals of thymol added as a preservative. It was established that the presence of thymol did not affect the assay.

On examination of the assay method it was found that when a known amount of GAA was added to the urine after deproteinization, incomplete recovery was obtained. When GAA standards were prepared in diluted deproteinized urine, the same percentage recovery was obtained at each concentration of GAA. A different percentage recovery was obtained with different urine samples. Therefore a correction was made to the GAA level observed in each urine sample after calculating the percentage recovery of a known amount of added GAA. Complete recovery was obtained when GAA was added to plasma.

ARGININE-GLYCINE AMIDINOTRANSFERASE ASSAY The method used was a modification of that described by Walker (1960). Tissues were homogenized in $0 \cdot 1 \mathrm{M}$ phosphate buffer $\mathrm{pH} 7 \cdot 4$ containing 0.001 M EDTA. Erythrocytes, leucocytes, cultured cells, and urine sediment were suspended in phosphate buffer and sonicated before assay. Urine sediment and supernatant were prepared by centrifugation of a 24-hour specimen (collected without preservative) at $8,000 \mathrm{~g}$ for $20 \mathrm{~min}$ at $4^{\circ} \mathrm{C} .250 \mathrm{ml}$. of the supernatant were dialized against water at $4^{\circ} \mathrm{C}$ for three days, and then freeze dried. The residue was dissolved in a small volume of phosphate buffer and assayed. The assay mixture for all determinations contained $0 \cdot 2$

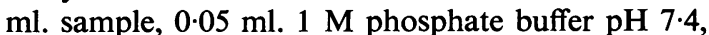
$0.05 \mathrm{ml} .1 \mathrm{M} \mathrm{L}$-arginine hydrocloride, and $0.1 \mathrm{ml}$. $2 \mathrm{M}$ hydroxylamine hydrochloride in $2 \mathrm{M}$ potassium hydroxide. After incubation at $37^{\circ} \mathrm{C}$, the reaction was terminated by the addition of $0.3 \mathrm{ml} .20 \%$ trichloroacetic acid. After centrifugation a $0.5 \mathrm{ml}$. portion of the supernatant was mixed with $0.5 \mathrm{ml}$. $1 \mathrm{M}$ phosphate buffer $\mathrm{pH} 7.0$ and $0.1 \mathrm{ml}$. acetone and then $0.1 \mathrm{ml} .1 \%$ ammonium disodium pentacyanoferrate was added. After 20 min extinction was read at $480 \mathrm{~nm}$. In each assay two blanks were used:

TABLE 1

URINARY EXCRETION OF GUANIDOACETIC ACID

\begin{tabular}{|c|c|c|c|c|}
\hline & \multicolumn{2}{|c|}{ Controls } & \multicolumn{2}{|c|}{ Myotonic dystrophy } \\
\hline & Males & Females & Males & Females \\
\hline $\begin{array}{l}\text { Subjects (no.) } \\
\text { Age range (yr) } \\
\text { GAA (mg/24 hr) } \\
\text { GAA (mg/24 hr/ } \\
\text { body wt) }\end{array}$ & $\begin{array}{c}13 \\
22-45 \\
43 \cdot 8 \pm 9 \cdot 6 \\
0 \cdot 61 \pm 0 \cdot 13\end{array}$ & $\begin{array}{c}13 \\
23-57 \\
52 \cdot 5 \pm 25 \cdot 2 \\
0 \cdot 93 \pm 0 \cdot 41\end{array}$ & $\begin{array}{c}7 \\
29-58 \\
41 \cdot 1 \pm 19 \cdot 5 \\
0 \cdot 67 \pm 0 \cdot 35\end{array}$ & $\begin{array}{c}4 \\
20-31 \\
42 \cdot 3 \pm 9 \cdot 9 \\
0 \cdot 86 \pm 0 \cdot 27\end{array}$ \\
\hline
\end{tabular}

Results expressed as mean \pm standard deviation. in one, the homogenate was replaced by buffer and in the other, arginine was replaced by water. All $\mathbb{\perp}$ samples were read against a reference sample in which both homogenate and substrate were omitted. In an attempt to detect low levels of enzyme activity, the reaction mixture was incubated at $37^{\circ} \mathrm{C}$ for 0 periods of up to five hours. Experiments using human kidney cortex showed that the rate of enzyme action was linear up to five hours.

Total protein determinations were carried out according to the method of Papadopoulos, Hess, O’Doherty, and McLane (1959).

\section{RESULTS}

Fasting plasma GAA levels were determined in six patients with myotonic dystrophy and in seven controls. The levels in all cases were close to the limit of sensitivity of the assay, being less $\vec{c}$ than $0.35 \mathrm{mg} / 100 \mathrm{ml}$. There was no apparent difference between the values obtained in the patients and in the controls.

The urinary excretion of GAA in healthy indi- of viduals was unrelated to age but was significantly $\%$ greater in females than in males when expressed as $\mathrm{mg}$ of GAA excreted $/ 24 \mathrm{hr} / \mathrm{kg}$ body weiglit 을 $(P<0.02)$. There was greater variability in the results from females than from males. For the reasons the values for patients and controls off the same sex were compared (Table 1). The re sults show that there is no significant difference in the urinary excretion of GAA between pa $\overrightarrow{0}$ tients with myotonic dystrophy and controls. ? There was greater variability in the values for 0 affected males than for control males, but this variability did not appear to be related to the severity of the disease.

The presence of AGA activity in renal cortical tissue was confirmed. Assay of enzyme activity in necropsy and biopsy material from individuals with no evidence of renal disease and no neuromuscular disorder gave a value for one biopsy specimen within the range observed for six necropsy specimens. However, enzyme activity in biopsy specimens from three kidneys with calculi was significantly greater than in healthy kidneys (Table 2).

AGA activity could not be detected in any of 윽 the following tissues obtained from healthy con- $D$ trols: plasma, erythrocytes, leucocytes (uncul- 을. tured and cultured for 72 hours with phyto- N haemagglutinin), whole skin and cultured skin 
TABLE 2

ARGININE-GLYCINE AMIDINOTRANSFERASE ACTIVITY IN KIDNEY CORTEX

\begin{tabular}{|c|c|c|c|c|}
\hline $\begin{array}{l}\text { Source of } \\
\text { material }\end{array}$ & $\begin{array}{l}\text { Condition } \\
\text { of kidney }\end{array}$ & $\begin{array}{l}\text { Specimens } \\
\text { (no.) }\end{array}$ & $\begin{array}{l}\text { Age } \\
\text { range } \\
(y r)\end{array}$ & $\begin{array}{c}\text { AGA activity } \\
(\text { n-mole/min/ } \\
100 \mathrm{mg} \text { protein })\end{array}$ \\
\hline Necropsy & $\begin{array}{c}\text { No evidence } \\
\text { of disease }\end{array}$ & 6 & $40-69$ & $167 \cdot 0 \pm 42 \cdot 7$ \\
\hline Biopsy & Healthy & 1 & 40 & $128 \cdot 5$ \\
\hline Biopsy & Calculi & 3 & $40-60$ & $340 \cdot 8 \pm 12 \cdot 2$ \\
\hline
\end{tabular}

Results expressed as mean \pm standard deviation.

fibroblasts, muscle tissue and cultured myoblasts, cerebrospinal fluid, and sediment and concentrated supernatant from 24 hour specimens of urine.

Since aspirin is known to cause shedding of renal tubular cells into the urine (Scott, Denman, and Dorling, 1963; Prescott, 1965), an attempt was made to produce measurable enzyme activity in urinary sediment by administering aspirin to a healthy male subject and collecting serial urine samples at 16 hour intervals up to 64 hours. Even after administration of $3 \mathrm{~g}$ aspirin, only very low enzyme activity was detectable in the urine sediment, this activity being confined to the sample collected between 16 and 32 hours after treatment. Because this enzyme activity was so low in a healthy individual it did not seem justified to extend this investigation to patients with myotonic dystrophy.

\section{DISCUSSION}

Since no significant abnormality was detected in plasma levels or urinary excretion of GAA in patients with myotonic dystrophy, it seems unlikely that there is a defect in GAA synthesis associated with this disease. AGA activity could not be detected in a number of easily accessible tissues from healthy controls. Thus if the reported decrease in AGA activity in myotonic dystrophy (Harvey, 1969) is to be further investigated there is no alternative but to study kidney, liver, or pancreatic tissues. However, it seems unjustified to subject patients to the dangers of taking biopsies from such tissues, since the present study gave no evidence for suspecting any abnormality in the synthesis of GAA in myotonic dystrophy.

We would like to express our thanks to Miss $\mathbf{L}$. Shearer for her excellent technical assistance and to Mr. Selby Tulloch and his staff for supplying biopsy specimens of kidney tissue. This work was supported by a grant from the Muscular Dystrophy Group of Great Britain.

\section{REFERENCES}

Harvey, J. C. (1962). Myotonia dystrophica. Transactions of the American Clinical and Climatological Association, 74, 176-191.

Harvey, J. C. (1969). Reduced renal arginine-glycine transamidinase activity in myotonic goats and in patients with myotonic muscular dystrophy. Johns Hopkins Medical Journal, 125, 270-275.

Milhorat, A. T. (1953). Creatine and creatinine metabolism and diseases of the neuro-muscular system. Proceedings. Association for Research in Nervous and Mental Diseases, 32, 400-421.

Papadopoulos, N. M., Hess, W. C., O'Doherty, D., and McLane, J. E. (1959). A procedure for the determination of cerebrospinal fluid total protein and gamma globulin in neurologic disorders. Clinical Chemistry, 5, 569-574.

Prescott, L. F. (1965). Effects of acetylsalicylic acid, phenacetin, paracetamol, and caffeine on renal tubular epithelium. Lancet, 2, 91-96.

Sandberg, A. A., Hecht, H. H., and Tyler, F. H. (1953). Studies in disorders of muscle. X. The site of creatine synthesis in the human. Metabolism, 2, 22-29.

Scott, J. T., Denman, A. M., and Dorling, J. (1963). Renal irritation caused by salicylates. Lancet, 1, 344-348.

Van Pilsum, J. F., Martin, R. P., Kito, E., and Hess, J. (1956). Determination of creatine, creatinine, arginine, guanidinoacetic acid, guanidine, and methylguanidine in biological fluids. Journal of Biological Chemistry, 222, 225236.

Van Pilsum, J. F., and Wolin, E. A. (1958). Guanidinium compounds in blood and urine of patients suffering from muscle disorders. Journal of Laboratory and Clinical Medicine, 51, 219-223.

Walker, J. B. (1960). Metabolic control of creatine biosynthesis. 1. Effect of dietary creatine. Journal of Biological Chemistry, 235, 2357-2361.

Walker, J. B. (1963). Formamidine group transfer in extracts of human pancreas, liver and kidney. Biochimica Biophysica Acta, 73, 241-247.

Zierler, K. L., Folk, B. P., Magladery, J. W., and Lilienthal, J. L. (1949). On creatinuria in man. The roles of the renal tubule and of muscle mass. Bulletin of the Johns Hopkins Hospital, 86, 370-395. 